\title{
Estimation of grain productivity and biochemical indicators of the winter bread wheat varieties depending on the forecrop
}

\author{
Olesya Nekrasova $^{1, *}$, Nina Kravchenko $^{1}$, Dmitry Marchenko ${ }^{1}$, and Evgeny Nekrasov ${ }^{1}$ \\ ${ }^{1}$ Agricultural Research Center "Donskoy”, Nauchny Gorodok Str., 3, 347740, Zernograd, Rostov \\ region, Russia
}

\begin{abstract}
The purpose of the study was to estimate the effect of sunflower and pea on the amount of productivity, protein and gluten percentage in grain. The objects of the study were 13 winter bread wheat varieties (Triticum aestivum L.) developed by the Agricultural Research Center "Donskoy". The study was carried out in 2018-2020 on the fields of the department of winter wheat breeding and seed production. The forecrops were peas and sunflower. The study results showed that the varieties 'Volny Don' (6.1 t / ha), 'Krasa Dona' (6.1 t / ha) and 'Lidiya' $(6.0 \mathrm{t} / \mathrm{ha})$, when sown after peas, gave the largest yields. The varieties 'Volny Don' (4.9 t / ha) and 'Polina' ( $4.8 \mathrm{t} / \mathrm{ha}$ ) which were sown after sunflower, showed the best productivity. The analysis of qualitative indicators established that the maximum percentage of protein and gluten in grain was identified in the varieties 'Podarok Krymu' (16.3\%; $28.3 \%)$ and 'Volnitsa' $(16.1 \% ; 28.5 \%)$, which were sown after peas; and the same varieties showed good results ('Podarok Krymu' (16.2\%; $27.4 \%)$ and 'Volnitsa' $(15.7 \%$; $27.8 \%)$ ), when sown after sunflower.
\end{abstract}

\section{Introduction}

Grain production is the basis for the entire agricultural sector of the Russian Federation. Winter grain crops play an important role in improving grain production. Compared to spring grain crops, they use 2 winter and early spring moisture reserves more efficiently; plants are able to avoid the harmful effects of drought. [1,2].

In winter bread wheat breeding an important direction is to improve the indicators of technological and biochemical properties of grain and maintain its high quality under various soil and climatic conditions $[3,4,5,6]$. The combination of these directions can ensure the development of the most productive and adaptive varieties.

It is common knowledge that a variety is a basis for the production of any crop. It largely determines the regional cultivation technologies, the amount of productivity, the chemical composition of grain and the energy efficiency of the obtained products $[7,8]$.

To conduct targeted work to improve the grain quality, it is necessary to know the effect of the properly selected parental forms, the inheritance of qualitative traits, value of

\footnotetext{
* Corresponding author: nekrasova_olesya@rambler.ru
} 
combination, adaptability to the growing conditions of hybridized varieties and, on this basis, to select parental forms properly. The choice of the forecrop has also a great influence on the quality indicators of winter bread wheat grain $[9,10]$.

The breeding work to increase the protein and gluten percentage in grain is associated with difficulties, including the absence of reliable genetic material with high protein percentage, a large phenotypic variability of this indicator, an effect of weather conditions during the period of grain filling, a significant negative correlation between protein/gluten percentage and productivity $[11,12,13,14,15,16]$.

The urgent direction of the study is to develop and introduce into production winter bread wheat varieties with a high potential for productivity and grain quality, well adapted to and able to maintain these properties under changing growing conditions.

The purpose of the study was to estimate the effect of sunflower and pea on the amount of productivity, protein and gluten percentage in grain.

\section{Materials and methods}

The objects of the study were 13 winter bread wheat varieties (Triticum aestivum L.) developed by the Agricultural Research Center "Donskoy". The study was carried out in 2018-2020 on the fields of the department of winter wheat breeding and seed production. The forecrops were peas and sunflower. The variety 'Don 107' was taken as a standard. The soil of the experimental plot was ordinary carbonate heavy loamy blackearth (chernozem), with a high carbonate content (from 2.5 to $4.0 \% \mathrm{CaCO}_{3}$ ). There was $3.6-4.0 \%$ of humus, $20-23 \mathrm{mg} / \mathrm{kg}$ of movable phosphorus and $300-380 \mathrm{mg} / \mathrm{kg}$ of exchangeable potassium in soil.

The climate of this area is characterized with semi-arid hot summers and moderately mild winters. During the growing season of plants, the sum of positive temperatures averages $3450{ }^{\circ} \mathrm{C}$, the average annual air temperature is $+9.7{ }^{\circ} \mathrm{C}$, the average annual precipitation is $588.8 \mathrm{~mm}$.

In 2018 there was an increased temperature regime in the spring-summer period and an uneven distribution of precipitation throughout the year. The average annual air temperature was $11.8{ }^{\circ} \mathrm{C}$, exceeding the average annual data by $2.1{ }^{\circ} \mathrm{C}$. In total there were $453.6 \mathrm{~mm}$ of precipitation during the agricultural year (77.0\% of the average annual norm).

The average daily air temperature in 2019 was $11.5^{\circ} \mathrm{C}$, which was on $1.8^{\circ} \mathrm{C}$ higher than the average annual temperature. There was an uneven precipitation distribution by seasons and months, and their sum was $521.4 \mathrm{~mm}$, that was less than the average long-term indicators $(88.6 \%$ of the norm) (Fig. 1). 


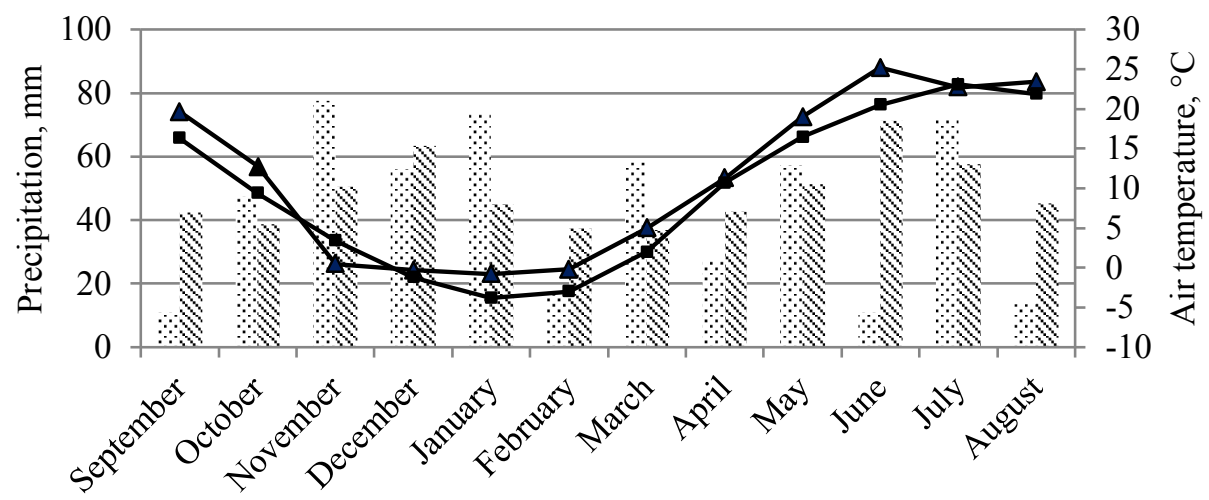

Precipitation amount, mm mean monthly

wo: Precipitation, mm mean annual

$\neg$ Temperature, ${ }^{\circ} \mathrm{C}$ average monthly

$\rightarrow-$ Temperature, ${ }^{\circ} \mathrm{C}$ mean annual

Fig. 1. Weather and climatic conditions, 2018-2019 agricultural year.

The year of 2020 was characterized by unfavorable conditions for the growth and development of winter wheat plants, especially in the spring. There was an increased temperature regime $\left(+1.6^{\circ} \mathrm{C}\right.$ to the long-term average $)$ and only $463.7 \mathrm{~mm}$ of precipitation (78.8\% of the average long-term norm) (Fig. 2).

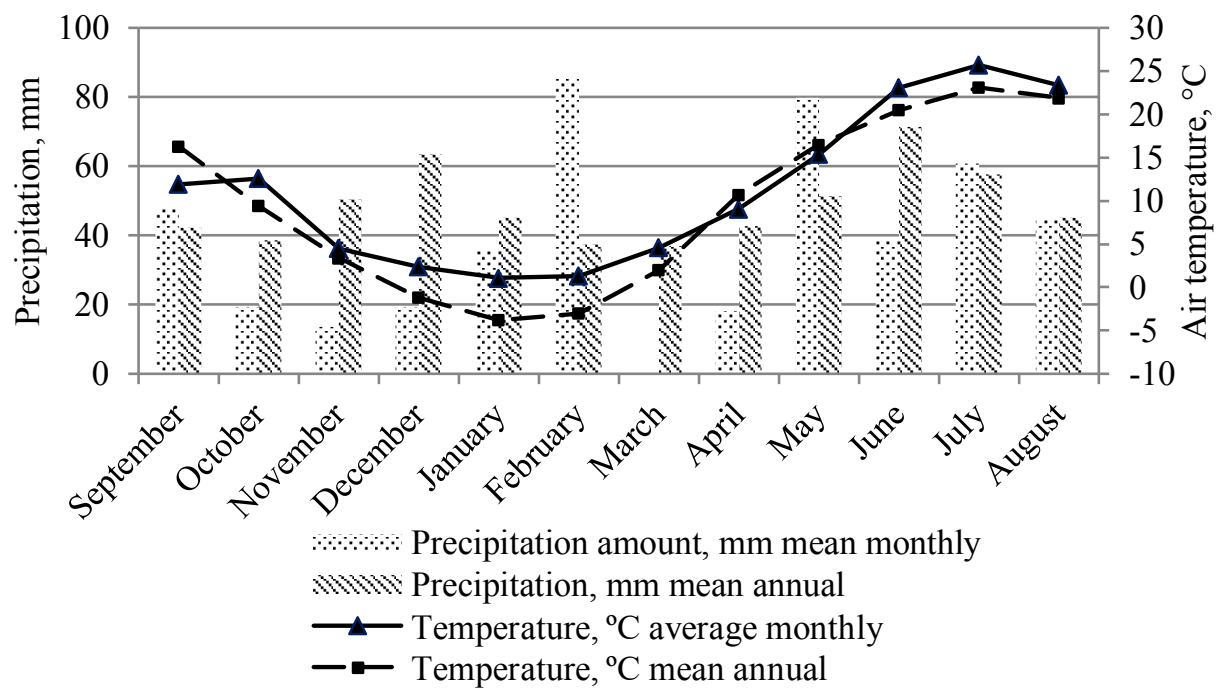

Fig. 2. Weather and climatic conditions, 2019-2020 agricultural year.

The mass fraction of protein and gluten percentage in grain of the winter bread wheat varieties were estimated in the laboratory for biochemical estimation of breeding material and grain quality of the Federal State Budgetary Scientific Institution "ANC "Donskoy" using the 'SpektraStar 2200' infrared analyzer.

Mathematical and statistical data processing was carried out according to the method of B.A. Dospekhov. 


\section{Result and discussion}

The peculiarity of row-crop forecrops is that they severely dry out the soil, as a result of which the plants fail to fully realize their potential for productivity and grain quality. It is important to select genotypes that can adapt to unfavorable growing conditions.

The amount of productivity is a resulting indicator of the functioning of all plant systems of winter bread wheat. The amount of productivity of the studied winter bread wheat varieties varied depending on the forecrop (Fig. 3).

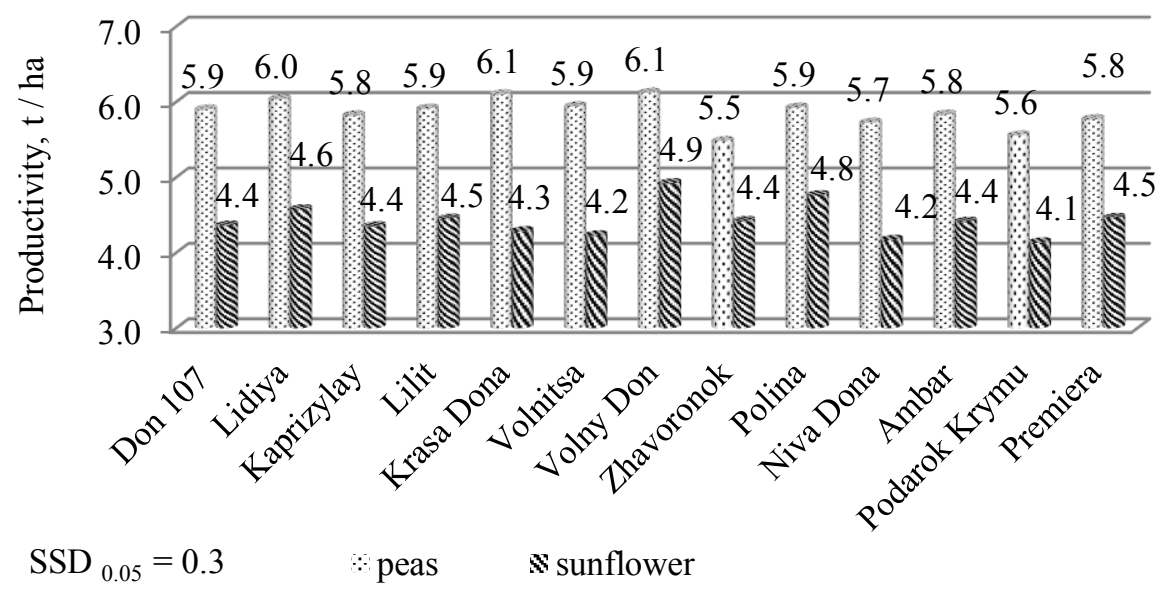

Fig. 3. Productivity of the winter bread wheat grain when sown after peas and sunflower, average in 2018-2020.

The maximum productivity of the studied varieties when sown after peas on average was given by the varieties 'Volny Don' ( $6.1 \mathrm{t} / \mathrm{ha})$, 'Krasa Dona' $(6.1 \mathrm{t} / \mathrm{ha})$ and 'Lidiya' $(6.0 \mathrm{t} / \mathrm{ha})$. The minimum grain productivity was shown by the variety 'Zhavoronok' $(5.5 \mathrm{t}$ / ha). When sown after sunflower the varieties 'Volny Don' (4.9 t / ha) and 'Polina' (4.8 t / ha) produced the largest yields. The minimum productivity was produced by the varieties 'Podarok Krymu' (4.1 t / ha), 'Niva Dona' (4.2 t/ ha) and 'Volnitsa' (4.2 t / ha).

The decrease of winter bread wheat productivity ranged from $1.1 \mathrm{t} /$ ha (the varieties 'Zhavoronok', 'Niva Dona') to $1.8 \mathrm{t}$ / ha (the variety 'Krasa Dona').

In order to establish the degree of the effect of growing conditions and genotype on the productivity of the winter wheat varieties, there was conducted a two-factor analysis of variance. It has been found that the values of Ffact 'genotype', 'environment' and their correlation exceeded the value of Ftheor, which allowed considering the values obtained in the trial as reliable. The effect of factors on the productivity of the varieties was uneven. The main effect was made by factor B ('environment') (71.5\%), and the effect of factor A ('genotype') was $8.8 \%$. The correlation between the factors was $5.3 \%$.

In addition to estimation of the amount of productivity there was conducted an estimation of their quality indicators.

The protein percentage in grain is an important biochemical trait that affects the processing properties of flour and dough and the nutritional value of the final product.

The amount of protein in the grain of the winter bread wheat varieties when sown after peas varied from $14.8 \%$ (the variety 'Premiera') to $16.3 \%$ (the variety 'Podarok Krymu') (Fig. 4). 


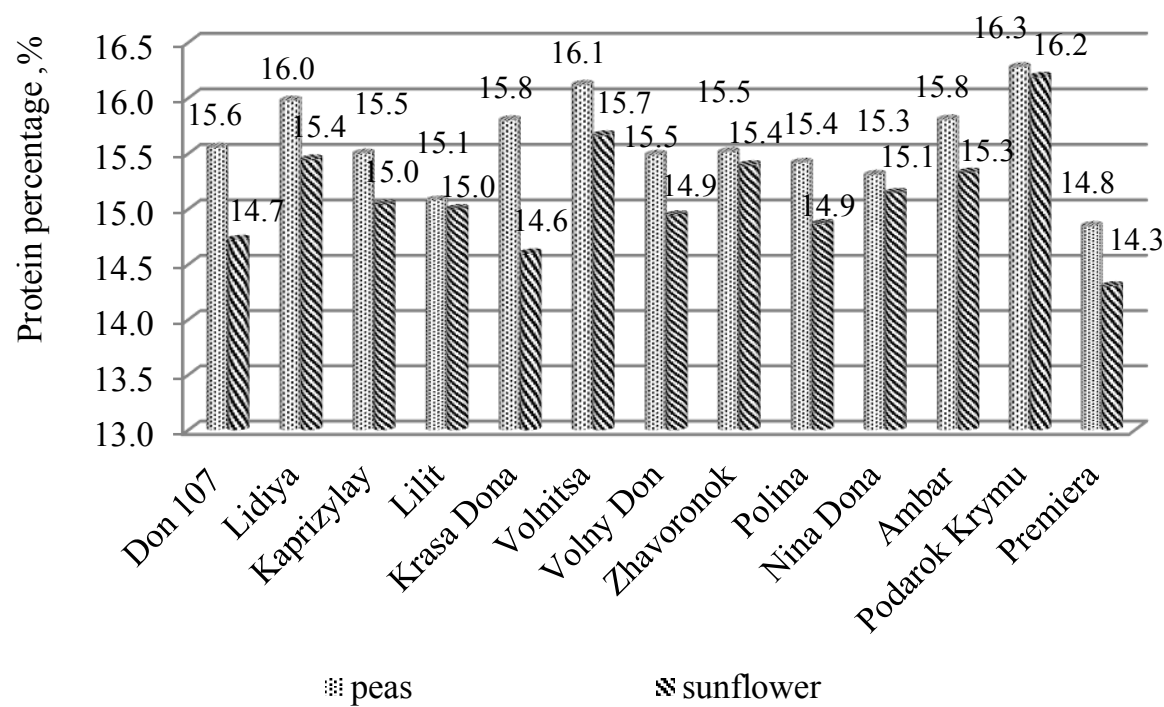

Fig. 4. Protein percentage in grain of the winter bread wheat varieties when sown after peas and sunflower, average in 2018-2020.

The analysis of the conducted study showed that there were identified the varieties 'Lidiya' (16.0\%), 'Volnitsa' (16.1\%) and 'Podarok Krymu' (16.3\%) with the large protein percentage in grain.

The protein percentage in grain of the varieties when sown after sunflower ranged from $14.3 \%$ ('Premiera') to $16.2 \%$ ('Podarok Krymu'). There were identified the varieties 'Zhavoronok', 'Volnitsa' and 'Podarok Krymu', which showed a maximum protein percentage in grain $(15.4 \%, 15.7 \%$ and $16.2 \%$, respectively).

It should be noted that, the forecrop did not significantly affect protein percentage in grain of the studied winter wheat varieties.

In order to establish the degree of the effect of growing conditions and genotype on the protein formation, there was conducted a two-factor analysis of variance. As a result of the analysis, that the values of $F_{\text {fact }}$ 'genotype', 'environment' and their correlation exceeded the value of $F_{\text {theor, }}$, which proved the reliability of the obtained study results (table 1).

Table 1. The results of two-factor analysis of variance of the winter bread wheat varieties by protein percentage in grain.

\begin{tabular}{|l|c|c|c|c|c|c|}
\hline \multicolumn{1}{|c|}{$\begin{array}{c}\text { Sources of } \\
\text { variation }\end{array}$} & $\begin{array}{c}\text { Sum of } \\
\text { squares }\end{array}$ & $\begin{array}{c}\text { Freedom } \\
\text { degree }\end{array}$ & Variance & $\mathbf{F}_{\text {fact }}$ & $\mathbf{F}_{\text {tab095. }}$ & Effect. \% \\
\hline $\begin{array}{l}\text { Factor A } \\
\text { (genotype) }\end{array}$ & 8.5 & 12.0 & 0.7 & 25.1 & 2.2 & 44.5 \\
\hline $\begin{array}{l}\text { Factor B } \\
\text { (environment) }\end{array}$ & 6.2 & 1.0 & 6.2 & 219.7 & 4.2 & 32.4 \\
\hline $\begin{array}{l}\text { Correlation } \\
\text { AxB }\end{array}$ & 0.9 & 12.0 & 0.1 & 2.7 & 2.2 & 4.8 \\
\hline
\end{tabular}

After studying the factors that affected the protein percentage in grain of the winter bread wheat varieties, there was found that they unevenly affected the studied indicator. Factor A ('genotype') (44.5\%) had the main effect on the accumulation of protein in grain, while the effect of Factor B ('environment') was $32.4 \%$. The correlation between factors was $4.8 \%$. 
Another equally important indicator of grain quality is gluten content in grain. Gluten is a complex of protein substances of grain, capable of forming a coherent elastic substance when swollen in water. Its content in grain and flour largely determines the quality of bread products. On average, over the years of study, the amount of gluten in grain of the winter wheat varieties when sown after peas varied from $25.0 \%$ (the variety 'Premiera') to $28.5 \%$ (the variety 'Volnitsa') (Fig. 5).

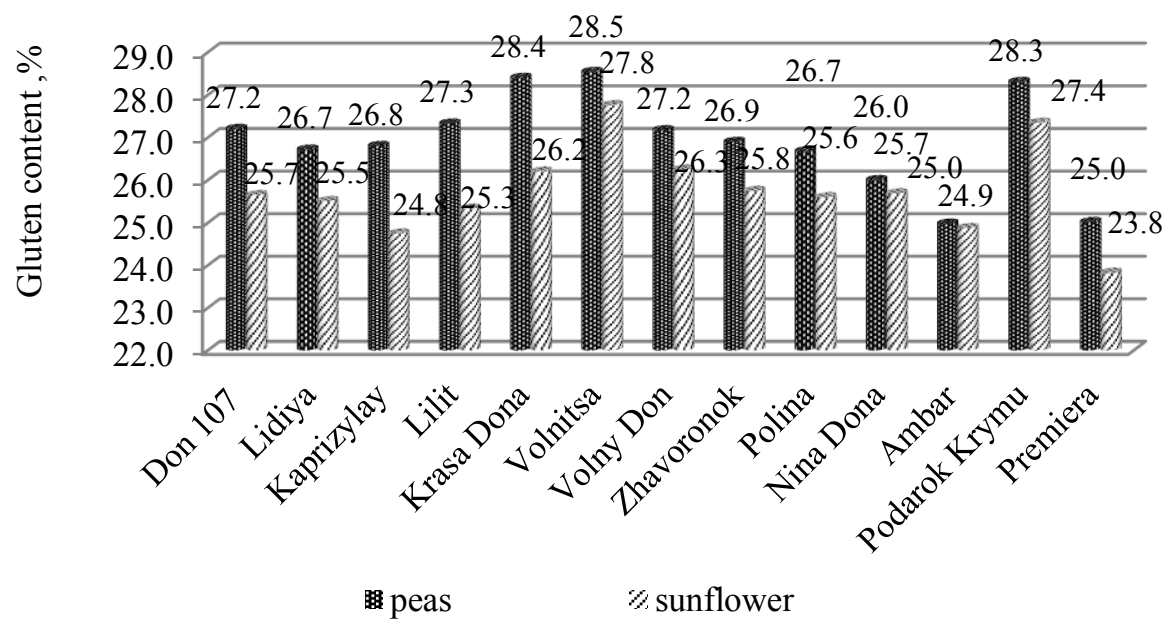

Fig. 5. Gluten content in grain of the winter bread wheat varieties when sown after peas and sunflower, average in 2018-2020.

There were identified the varieties 'Podarok Krymu', 'Krasa Dona' and 'Volnitsa' which formed the maximum amount of gluten in grain $(28.3 \%, 28.4 \%$ and $28.5 \%$, respectively).

The amount of gluten in grain of the varieties when sown after sunflower ranged from $23.8 \%$ (the variety 'Premiera') to $27.8 \%$ (the variety 'Volnitsa'). The largest values of the gluten in grain were identified in the varieties 'Volny Don' $(26.3 \%)$, 'Podarok Krymu' (27.4\%) and 'Volnitsa' (27.8\%).

It should be noted that, despite a significant decrease in grain productivity due to a definite forecrop (peas or sunflower), there was no significant decrease in the amount of gluten in grain.

Estimation of the degree of the effect of factors on the amount of gluten in grain showed that the main influence was made by Factor A ('genotype') (56.8\%), and Factor B ('environment') $(23.8 \%)$. The correlation between the factors was reliable and amounted to $6.8 \%$. (Table 2).

Table 2. The results of two-factor analysis of variance of the winter bread wheat varieties by gluten content in grain.

\begin{tabular}{|l|c|c|c|c|c|c|}
\hline Sources of variation & $\begin{array}{c}\text { Sum of } \\
\text { squares }\end{array}$ & $\begin{array}{c}\text { Freedom } \\
\text { degree }\end{array}$ & Variance & $\mathbf{F}_{\text {fact }}$ & $\mathbf{F}_{\text {tab095. }}$ & Effect. \% \\
\hline Factor A (genotype) & 70.2 & 12.0 & 5.9 & 19.0 & 2.2 & 56.8 \\
\hline Factor B (environment) & 29.4 & 1.0 & 29.4 & 95.6 & 4.2 & 23.8 \\
\hline Correlation AxB & 8.4 & 12.0 & 0.7 & 2.3 & 2.2 & 6.8 \\
\hline
\end{tabular}

\section{Conclusions}


Wheat, when sown after tough row-crop forecrops, in particular after sunflower, is in worse conditions in terms of plant nutrition and water supply compared to such forecrop as peas.

The study results showed that the varieties 'Volny Don' $(6.1 \mathrm{t} / \mathrm{ha})$, 'Krasa Dona' $(6.1 \mathrm{t}$ / ha) and 'Lidiya' (6.0 t / ha), when sown after peas, gave the largest yields. The varieties 'Volny Don' ( $4.9 \mathrm{t} / \mathrm{ha}$ ) and 'Polina' (4.8 t / ha) which were sown after sunflower, showed the best productivity.

The analysis of qualitative indicators identified a slight effect of the used forecrops (peas and sunflower) on protein and gluten percentage in grain.

The maximum percentage of protein and gluten in grain was identified in the varieties 'Podarok Krymu' $(16.3 \%$; 28.3\%) and 'Volnitsa' (16.1\%; 28.5\%), which were sown after peas; and the same varieties showed good results ('Podarok Krymu' $(16.2 \% ; 27.4 \%$ ) and 'Volnitsa' $(15.7 \% ; 27.8 \%))$, when sown after sunflower.

\section{References}

1. A. Rehman, L. Jingdong, B. Shahzad et al., Pacific Science Review B: Humanities and Social Sciences 1, 145-158 (2015)

2. A. Kuryleva, Agricultural Science of the Euro-North-East. 21(5), 503-511 (2020) doi: 10.30766 / 2072-9081.2020.21.5.503-511

3. G. Syzdykova, S. Sereda, N. Malitskaya, Agricultural Biology 53(1), 103-110 (2018) doi: 10.15389 / agrobiology.2018.1.103rus

4. L. Kong, J. Si, B. Zhang, B. Feng, Sh. Li, F. Wang, AJCS 7(2), 173-181 (2013)

5. M. Hawkesford, J. Luis Araus, R. Park, D. Calderini, Food Energy Security 2, 34-48 (2013)

6. P. Park Vitale, J. Vitale, F. Epplin, Agric. Appl. Econom. 51, 69-103 (2019) doi:10.1017/aae.2018.24

7. L. Volkova, Agricultural Science of the Euro-North-East 2, 4-8 (2016)

8. V. Kozlov, Journal of Genetics and Breeding 17(3), 541-557 (2013)

9. Aigyl Abugalieva T. Savin, Vavilov Journal of Genetics and Breeding 22(3), 353-362 (2018) doi: 10.18699 / VJ18.371.

10. V. Kovtunov, N. Kovtunova, O. Lushpina et al., Grain Economy of Russia 1(55), 17 20 (2018).

11. P. Stepochkin, Journal of Genetics and Breeding 16(1), 33-36 (2012)

12. V. Zecevic, J. Boskovic, D. Knezevic, D. Micanovic, Agricultural research 74(1), 2328 (2014) doi:10.4067/S0718-58392014000100004

13. I. Adonina, I. Leonova, E. Badaeva et al., Journal of Genetics and Breeding 20(1), 4450 (2016) doi: 10.18699 / VJ16.107

14. L. Petrov, V. Selekhov, Agricultural Science of the Euro-North-East 2(51), 24-28 (2016).

15. Ch. Zörb, U. Ludewig, M.J. Hawkesford, Trends Plant Sci. 23(11), 1029-1037 (2018) doi: 10.1016/j.tplants.2018.08.012.

16. O. Nekrasova, N. Kravchenko, N. Ignatieva et al., Grain Economy of Russia 4(70), 3135 (2020) doi: 10.31367 / 2079-8725-2020-70-4 -31-35. 